\title{
Metabolism of carveol and dihydrocarveol in Rhodococcus erythropolis DCL14
}

\author{
Mariët J. van der Werf $†$ and Anneke M. Boot
}

Division of Industrial Microbiology, Department of Food Technology and Nutritional Sciences, Wageningen University, PO Box 8129, 6700 EV Wageningen, The Netherlands
Author for correspondence: Mariët J. van der Werf. Tel: +31 30 6944071. Fax: +31306944466. e-mail: vanderWerf@voeding.tno.nl

Rhodococcus erythropolis DCL14 assimilates all stereoisomers of carveol and dihydrocarveol as sole source of carbon and energy. Induction experiments with carveol- or dihydrocarveol-grown cells showed high oxygen consumption rates with these two compounds and with carvone and dihydrocarvone. (Dihydro)carveol-grown cells of R. erythropolis DCL14 contained the following enzymic activities involved in the carveol and dihydrocarveol degradation pathways of this micro-organism: (dihydro)carveol dehydrogenase (both $\mathrm{NAD}^{+}$- and dichlorophenolindophenol-dependent activities), an unknown cofactor-dependent carvone reductase, (iso-)dihydrocarvone isomerase activity, NADPH-dependent dihydrocarvone monooxygenase (Baeyer-Villiger monooxygenase), $\varepsilon$-lactone hydrolase and an NAD+-dependent 6-hydroxy-3isopropenylheptanoate dehydrogenase. Product accumulation studies identified $(4 R)$-carvone, $(1 R, 4 R)$-dihydrocarvone, $(4 R, 7 R)$-4-isopropenyl-7methyl-2-oxo-oxepanone, (3R)-6-hydroxy-3-isopropenylheptanoate, (3R)-3isopropenyl-6-oxoheptanoate, (3S,6R)-6-isopropenyl-3-methyl-2-oxooxepanone and (5R)-6-hydroxy-5-isopropenyl-2-methylhexanoate as intermediates in the $(4 R)$-carveol degradation pathway. The opposite stereoisomers of these compounds were identified in the (4S)-carveol degradation pathway. With dihydrocarveol, the same intermediates are involved except that carvone was absent. These results show that $R$. erythropolis DCL14 metabolizes all four diastereomers of carveol via oxidation to carvone, which is subsequently stereospecifically reduced to (1R)-(iso-) dihydrocarvone. At this point also dihydrocarveol enters the pathway, and this compound is directly oxidized to (iso-)dihydrocarvone. Cell extracts contained both (1R)-(iso-)dihydrocarvone 1,2-monooxygenase and (1S)-(iso)dihydrocarvone 2,3-monooxygenase activity, resulting in a branch point of the degradation pathway; (1R)-(iso-)dihydrocarvone was converted to 4isopropenyl-7-methyl-2-oxo-oxepanone, while (1S)-(iso)-dihydrocarvone, which in vivo is isomerized to (1R)-(iso-)dihydrocarvone, was converted to 6isopropenyl-3-methyl-2-oxo-oxepanone. 4-Isopropenyl-7-methyl-2-oxooxepanone is hydrolysed to 6-hydroxy-3-isopropenylheptanoate, which is subsequently oxidized to 3-isopropenyl-6-oxoheptanoate, thereby linking the (dihydro)carveol degradation pathways to the limonene degradation pathway of this micro-organism. 6-Isopropenyl-3-methyl-2-oxo-oxepanone is, in vitro, hydrolysed to 6-hydroxy-5-isopropenyl-2-methylhexanoate, which is thought to be a dead-end metabolite.

Keywords: monoterpene metabolism, Rhodococcus erythropolis, carveol, carvone, dihydrocarveol

† Present address: TNO-Voeding, Department of Applied Microbiology and Gene Technology, PO Box 360, 3700 AJ Zeist, The Netherlands. Abbreviation: DCPIP, dichlorophenolindophenol. 


\section{INTRODUCTION}

Terpenes, hydrocarbons built from isoprene units $\left(\mathrm{C}_{5}\right)$, are the largest class of plant secondary metabolites (Harbourne, 1991). During the last decade it has become apparent that monoterpenes play an important role in chemical ecology, where they act as attractants, repellents, sex pheromones, alerting pheromones or are a part of defence secretion systems against predators (Banthorpe, 1994). They are widely distributed in nature, and over over 30000 different naturally occurring terpenes have been identified (Buckingham, 1998). Volatile monoterpene emission from trees is estimated at $127 \times 10^{14} \mathrm{~g}$ carbon per year (Guenther et al., 1995). Remarkably, only little is known about the catabolic pathways by which monoterpenes are recycled in the biosphere (Trudgill, 1986, 1990, 1994).

Carvone (5-isopropenyl-2-methyl-2-cyclohexenone) (Fig. 1), a monocyclic monoterpene ketone, is produced by over 70 different plants (Burdock, 1995). It exists in two stereoisomeric forms; $(-)-(4 R)$-carvone, which is the main component in the essential oil of spearmint (Mentha spicata), and (+)-(4S)-carvone, which is the main component in the essential oils of caraway (Carum carvi) and dill (Anethum graveolens) (Ravid et al., 1992). Especially (4R)-carvone, which has a spearmint flavour, but also $(4 S)$-carvone, which has an odour reminiscent of caraway, are natural flavours widely applied by the flavour and fragrance industry (Welsh et al., 1989). Natural carvone is produced by extraction from plant material. In plants, carvone is formed in a biosynthetic pathway from limonene via hydroxylation at the $\mathrm{C} 6$ position, forming carveol, and subsequent oxidation of carveol to carvone (McCaskill \& Croteau, 1997).

To date, not a lot of information has been published about the microbial metabolism of carveol or carvone. Previously, the bioconversion of these monoterpenes by bacteria (Noma, 1980; Noma \& Nishimura, 1987; Noma et al., 1974, 1975, 1982; Nishimura et al., 1983; Verstegen-Kaaksma et al., 1995), yeast (Mirconowicz \& Siewiński, 1986; Mirconowicz et al., 1982, van Dyk et al., 1998, Varie et al., 1998), fungi (Noma \& Nonomura, 1974; Verstegen-Kaaksma et al., 1995) and algae (Noma \& Asakawa, 1992; Shimoda et al., 1998) has been reported. These studies showed that carveol was converted into carvone, dihydrocarvone and dihydrocarveol (Fig. 1). However, not one of these micro-organisms was able to utilize either carveol or carvone as a growth substrate and the enzymes involved in these bioconversions were not characterized. Only one activity involved in the bioconversion of carvone, iso-dihydrocarvone isomerase, has been partially purified from Pseudomonas fragi (Noma et al., 1975). However, it is not clear if this activity was catalysed by an enzyme.

Recently, we isolated Rhodococcus erythropolis DCL14, a strain able to grow not only on limonene, but also on all stereoisomers of 2-oxyfunctionalized limonene derivatives such as carveol, carvone, dihydrocarveol and dihydrocarvone as sole source of carbon and energy (van der Werf et al., 1999a). In this report we discuss the enzymic activities and intermediates involved in the degradation pathways of the different stereoisomers of these 2-oxyfunctionalized limonene derivatives in $R$. erythropolis DCL14.

\section{METHODS}

Strain and growth conditions. R. erythropolis DCL14 was previously isolated on $(4 R)$-dihydrocarveol (van der Werf et al., 1999a), and is maintained at the division of Industrial Microbiology (CIMW 0387B, Wageningen, the Netherlands). The strain was subcultured once a month and grown at $30^{\circ} \mathrm{C}$ on a yeast extract-glucose agar plate for $2 \mathrm{~d}$, after which the plates were stored at room temperature. It was grown in 5 litre Erlenmeyer flasks containing 1 litre of mineral salts medium (Hartmans et al., 1989) with $0.01 \%$ (v/v) carbon source and fitted with rubber stoppers. The flasks were incubated at $30^{\circ} \mathrm{C}$ on a horizontal shaker oscillating at $1 \mathrm{~Hz}$ with an amplitude of $10 \mathrm{~cm}$. After growth was observed, the concentration of the (toxic) substrate was increased in steps of $0.01 \%(\mathrm{v} / \mathrm{v})$ until a total of $0.1 \%(\mathrm{v} / \mathrm{v})$ carbon source had been added. It was critical not to add the next batch of substrate before the first batch was completely consumed, otherwise the cells were killed and growth was no longer observed. This amounted to the addition of substrate every $3 \mathrm{~d}$ at the beginning of the cultivation, reaching twice a day at the end of the cultivation. With succinate and (4S)-limonene-1,2diol, cultures were grown in a 5 litre Erlenmeyer flask containing 1 litre of mineral salts medium supplemented with $3 \mathrm{~g}$ of the pertinent carbon source per litre. With $(4 R)$ limonene, cells were cultivated in a fed-batch fermenter as described previously (van der Werf et al., 1998). Cells were collected by centrifugation $\left(4^{\circ} \mathrm{C}, 10 \mathrm{~min}\right.$ at $16000 \mathrm{~g}$ ) and washed with $50 \mathrm{mM}$ potassium phosphate buffer $\mathrm{pH} 7 \cdot 0$. The pellet was resuspended in $7 \mathrm{ml}$ of this buffer and stored at $-20{ }^{\circ} \mathrm{C}$ until used.

Respiration experiments. Substrate-dependent oxygen uptake experiments were performed with a biological oxygen monitor as described previously (Hartmans et al., 1989) by determining the difference in oxygen uptake rates of whole cells before (endogenous oxygen uptake rate) and after the addition of substrate. The terpene substrates were added by injecting $100 \mu \mathrm{l}$ of a $5 \mathrm{mM}$ stock solution in water to the reaction vessel ( $3 \mathrm{ml}$ total volume, $0.17 \mathrm{mM}$ final substrate concentration). In the case of the poorly water-soluble limonene, $1 \mu \mathrm{l}$ limonene was injected directly into the reaction vessel of the biological oxygen monitor. Protein was released from whole cells by boiling them for $10 \mathrm{~min}$ in $0.5 \mathrm{M} \mathrm{NaOH}$. Subsequently, the protein concentration was determined by the method of Bradford (1976) with BSA as the standard.

Preparation and dialysis of cell extracts. Cell extracts were prepared by sonication as described previously (van der Werf et al., 1999a). Crude extracts were dialysed against 500 vols $25 \mathrm{mM}$ potassium phosphate buffer $\left(\mathrm{pH} \mathrm{7 \cdot 0)}\right.$ ) for $16 \mathrm{~h}$ at $4{ }^{\circ} \mathrm{C}$.

Preparation of cofactor fraction. The cofactor fraction was prepared from extracts $\left(10 \mathrm{mg}\right.$ protein $\left.\mathrm{ml}^{-1}\right)$ of cells grown on (4S)-limonene-1,2-diol by ultracentrifugation with an Amicon ultrafiltration unit using a membrane with a cut-off of 10000 under nitrogen at a pressure of 4 bar. The clear filtrate collected was used as the cofactor fraction. The cofactor fraction could be stored at $-20{ }^{\circ} \mathrm{C}$ for at least 2 months without any significant loss of activity. 
Separation of dihydrocarvone monooxygenase and lactone hydrolase activity by hydrophobic interaction chromatography. Cell extract (7 ml, $150 \mathrm{mg}$ protein) was applied onto an Octyl Sepharose column $(2.5 \times 35 \mathrm{~cm})$ equilibrated with $20 \mathrm{mM}$ potassium phosphate buffer $(\mathrm{pH} 7 \cdot 0), 10 \%(\mathrm{w} / \mathrm{v})$ glycerol, $300 \mathrm{mM} \mathrm{NaCl}, 5 \mu \mathrm{M}$ FAD and $0 \cdot 1 \mathrm{mM}$ DTT $\left(4{ }^{\circ} \mathrm{C}\right.$, flow rate $0.75 \mathrm{ml} \mathrm{min}$; collected fraction volume was $7.5 \mathrm{ml}$ ). Lactone hydrolase binds to this column while dihydrocarvone monooxygenase does not. Fractions containing dihydrocarvone monooxygenase activity were pooled and adjusted to $80 \%$ ammonium sulfate saturation. After $15 \mathrm{~min}$ at $0{ }^{\circ} \mathrm{C}$, the precipitate was collected by centrifugation $(15 \mathrm{~min}$ at $27000 \mathrm{~g}$ ). The pellet was resuspended in $5 \mathrm{ml}$ of the same buffer as used for column chromatography except that the $\mathrm{NaCl}$ concentration was $100 \mathrm{mM}$.

Enzyme assays. All assays were performed at $30^{\circ} \mathrm{C}$ with freshly prepared cell extracts. Specific activities determined spectrophotometrically were calculated from the linear part of the reaction and values for activity were determined from a minimum of two separate measurements. The reactions were started by the addition of the substrate, and the rates were corrected for endogenous activity. Protein was determined by the method of Bradford (1976) with BSA as the standard. Specific activities were expressed in $\mathrm{nmol} \mathrm{min}^{-1}(\mathrm{mg} \text { protein })^{-1}$.

$\mathrm{NAD}(\mathrm{P})^{+}$- and dichlorophenolindophenol (DCPIP)-dependent (dihydro)carveol dehydrogenase activities were determined spectrophotometrically as described previously (van der Werf et al., 1999b), except that $50 \mathrm{mM}$ glycine/ $\mathrm{NaOH}$ (pH 10.5) was used as the buffer for the $\mathrm{NAD}(\mathrm{P})^{+}$-dependent activity. Carvone reductase was determined by monitoring carvone degradation by GC. The reaction mixtures (total volume $1.0 \mathrm{ml}$ ) contained $50 \mathrm{mM}$ Tris $/ \mathrm{HCl}$ buffer $(\mathrm{pH} 8.0), 1 \mathrm{mM}$ carvone, $400 \mu$ cofactor fraction (see above) and cell extract in $15 \mathrm{ml}$ vials fitted with Teflon Mininert valves (Supelco) to prevent evaporation of carvone. The reaction was started by the addition of carvone and the vials were placed in a water bath $\left(30^{\circ} \mathrm{C}\right)$. After different time points a vial was removed from the water bath and the reaction was terminated by the addition of $1 \mathrm{ml}$ ethyl acetate. The vials were vigorously shaken to accomplish quantitative extraction of the terpenes. The ethyl acetate layer was pipetted into a microcentrifuge tube and centrifuged $(3 \mathrm{~min}, 13000 \mathrm{~g}$ ) to achieve separation of the two layers. Subsequently $1 \mu \mathrm{l}$ of the ethyl acetate layer was analysed by GC. Dihydrocarvone monooxygenase was measured spectrophotometrically by following the oxidation of NADPH in a reaction mixture containing $50 \mathrm{mM}$ glycine/ $\mathrm{NaOH}$ (pH 9.5), 0.2 mM NADPH, $1 \mathrm{mM}$ dihydrocarvone, and cell extract. Lactone hydrolase was determined by monitoring degradation of $\varepsilon$-caprolactone, a commercially available substrate analogue, by GC as described previously (van der Werf et al., 1999a) except that $50 \mathrm{mM}$ Tris/ $\mathrm{HCl}(\mathrm{pH}$ 9.0) was used as the buffer. Isocitrate lyase (van der Werf et al., 1997) and L-(S)-malate dehydrogenase (van der Werf et al., 1999a), a constitutive enzyme determined as a measure of the activity of the cell extract, were measured spectrophotometrically as described previously.

Product accumulation and identification studies. Reaction mixtures $(1 \mathrm{ml})$, as described for the enzyme assays, were prepared in $15 \mathrm{ml}$ vials fitted with Teflon Mininert valves and substrates and products were analysed by GC. For product accumulation from carvone, the vials were flushed for $10 \mathrm{~min}$ with $\mathrm{N}_{2}$, after which the reaction was started by injecting cell extract into the vials. After different time points a vial was removed from the water bath $\left(30^{\circ} \mathrm{C}\right)$ and the reaction was terminated by the addition of $1 \mathrm{ml}$ ethyl acetate. In the case of studies resulting in the formation of fatty acids, $20 \mu \mathrm{l}$ of a $2 \mathrm{M}$ $\mathrm{H}_{2} \mathrm{SO}_{4}$ solution was also added to accomplish the extraction of the acid in the organic phase. The vials were vigorously shaken to accomplish quantitative extraction of the terpenes. The ethyl acetate layer was pipetted into a microcentrifuge tube and centrifuged $(3 \mathrm{~min}, 13000 \mathrm{~g}$ ) to achieve separation of the two layers. Subsequently $1 \mu$ of the ethyl acetate layer was analysed by GC.

For product identification studies, the biotransformations were done in an identical way but on a 10 times larger scale. At the end of the reaction, the liquid was extracted three times with 0.5 vol. hexane. The organic layers were combined, dried over $\mathrm{MgSO}_{4}$, and evaporated to dryness in a rotary evaporator under reduced pressure. The stereoisomers were assigned using a combination of chiral and non-chiral GC, and GCMS. With the products of $(4 R)$-dihydrocarvone, ${ }^{1} \mathrm{H}-\mathrm{NMR}$ and ${ }^{13} \mathrm{C}-\mathrm{NMR}$ spectral analyses were also performed. The data obtained were compared with those of authentic samples and/or literature data.

Analytical methods. All terpenes were analysed by chiral GC on a fused silica cyclodextrin capillary column $(\alpha$-DEX 120 column, $30 \mathrm{~m}$ length, $0 \cdot 25 \mathrm{~mm}$ internal diameter, $0 \cdot 25 \mu \mathrm{m}$ film coating; Supelco). GC was performed on a Chrompack CP9000 gas chromatograph equipped with a flame ionization detector using $\mathrm{N}_{2}$ as the carrier gas. The detector and injector temperatures were 250 and $200{ }^{\circ} \mathrm{C}$, respectively, and the split ratio was $1: 50$. The stereoisomers of carveol, dihydrocarveol, carvone, dihydrocarvone, 4-isopropenyl-7-methyl-2-oxooxepanone, 6-isopropenyl-3-methyl-2-oxo-oxepanone, 6hydroxy-3-isopropenylheptanoate, 3-isopropenyl-6-oxoheptanoate and 6-hydroxy-5-isopropenyl-2-methylhexanoate were analysed isocratically at an oven temperature of 110,110 , $80,110,140,140,170,170$ and $170{ }^{\circ} \mathrm{C}$, respectively.

GC-MS analyses were carried out on an HP5973 MSD gas chromatograph equipped with a fused silica capillary column (non-chiral GC; HP-5, $30 \mathrm{~m} \times 0.25 \mathrm{~mm}$ i.d., film thickness $0.25 \mu \mathrm{m})$. The carrier gas was $\mathrm{He}$ at a flow rate of $1.0 \mathrm{ml} \mathrm{min}{ }^{-1}$. Injector temperature, $220^{\circ} \mathrm{C}$; temperature programme, $70-250{ }^{\circ} \mathrm{C}$ at $7^{\circ} \mathrm{C} \mathrm{min}^{-1}$; on-line injection volume, $5 \mu \mathrm{l}$. Electron impact MS data were obtained at $70 \mathrm{eV} .{ }^{1} \mathrm{H}-\mathrm{NMR}$ and ${ }^{13} \mathrm{C}-\mathrm{NMR}$ spectra were recorded on a Bruker DPX 400 spectrometer at $400 \mathrm{~Hz}$.

Chemicals. In this paper the sequence rule of CahnIngold-Prelog is used to differentiate between the stereochemistries of the monoterpene stereoisomers rather than the older, still frequently used but somewhat confusing, $(+)$ and $(-)$ nomenclature. The carbon atom numbering is based on the standard carbon atom numbering of limonene. For the structures of the terpenes used, see Fig. 1.

$(-)-(4 R)$-Carveol [mixture of two diastereomers], $(+)-(4 R)$ limonene, $(-)-(R)$ - and $(+)-(S)$-carvone were from Acros. $\varepsilon^{-}$ Caprolactone was purchased from Aldrich and Octyl Sepharose was obtained from Pharmacia. (+)-(4R)Dihydrocarvone [mixture of $\approx 77 \%(+)-(1 R, 4 R)-$ and $\approx 20 \%(+)$-(1S,4R)-iso-dihydrocarvone], $(+)-(4 S)$-dihydrocarveol [mixture of $\approx 75 \%(+)-(1 S, 2 S, 4 S)-, \approx 3 \%(-)$ $(1 S, 2 R, 4 S)$-neo-, $\approx 13 \%(-)-(1 R, 2 S, 4 S)$-neoiso- and $\approx 6 \%$ $(-)-(1 R, 2 R, 4 S)$-iso-dihydrocarveol] and $(-)$-(4R)-dihydrocarveol [mixture of $\approx 75 \%(-)-(1 R, 2 R, 4 R)-, \approx 3 \%(+)$ $(1 R, 2 S, 4 R)$-neo-, $\approx 13 \%(+)-(1 S, 2 R, 4 R)$-neoiso- and $\approx 6 \%$ $(+)-(1 S, 2 S, 4 R)$-iso-dihydrocarveol] were from Fluka.

(4S)-Carveol [mixture of two diastereomers] (van der Werf et 

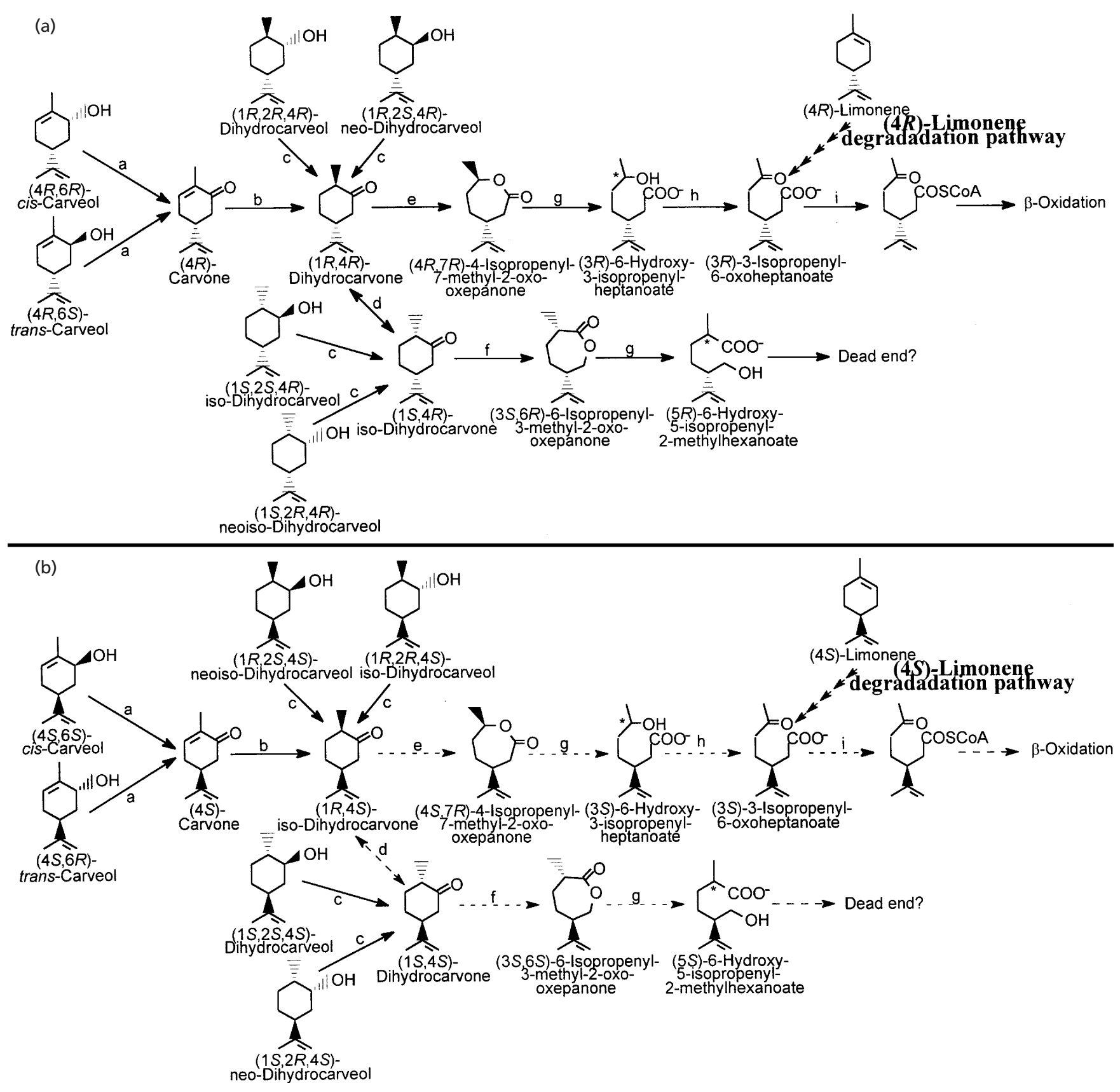

Fig. 1. Degradation pathways for the stereoisomers of carveol and dihydrocarveol in R. erythropolis DCL14. (a) Degradation pathway of the (4R)-stereoisomers. (b) Degradation pathway of the (4S)-stereoisomers. The letters on the arrows denote: a, carveol dehydrogenase; $b$, carvone reductase; $c$, dihydrocarveol dehydrogenase; d, dihydrocarvone isomerase activity; e, dihydrocarvone 1,2-monooxygenase; $f$, dihydrocarvone 2,3-monooxygenase; $g$, $\varepsilon$-lactone hydrolase; h, 6-hydroxy-3-isopropenylheptanoate dehydrogenase; i, 3-isopropenyl-6-oxoheptanoyl-CoA synthetase. Dashed lines represent ambiguous enzymic conversions. At the point of (3R)- or (3S)-isopropenyl-6-oxoheptanoate the $(R)$ - and (S)-limonene degradation pathways, respectively, of $R$. erythropolis DCL14 (van der Werf et al., 1999a) join the (dihydro)carveol degradation pathways.

al., 1999b) and 3-isopropenyl-6-oxoheptanoate (van der Werf et al., 1999a) were prepared as described previously. Reference samples of $(+)-(4 S, 6 S)$-cis- $(97 \cdot 8 \%),(+)-(4 S, 6 R)$-trans$(94.6 \%),(-)-(4 R, 6 R)$-cis- $(96.8 \%)$ and $(-)-(4 R, 6 S)$-transcarveol $(99.2 \%)$ were obtained after preparative GC separation (van der Werf et al., 1999b). Samples enriched in
$(1 S, 4 R)$-iso-dihydrocarvone $(80 \%$ pure) were prepared from $(4 R)$-dihydrocarvone by preparative GC as described previously for carveol (van der Werf et al., 1999b) except that an oven temperature of $95^{\circ} \mathrm{C}$ was used. Reference samples of optically pure $(1 R, 4 R)$ - and $(1 S, 4 R)$-iso-dihydrocarvone, $(1 R, 2 R, 4 R)-,(1 S, 2 R, 4 R)$-neoiso- and $(1 S, 2 S, 4 R)$-iso-dihydro- 
carveol were a kind gift of H. Swarts (Laboratory of Organic Chemistry, Wageningen University). Reference samples of 4isopropenyl-7-methyl-2-oxo-oxepanone and 6-isopropenyl3-methyl-2-oxo-oxepanone were synthesized from (4R)dihydrocarvone by oxidation with peracetate (Sauers \& Ahearn, 1961). To a solution of $100 \mu \mathrm{l}(4 R)$-dihydrocarvone in $0.5 \mathrm{ml}$ acetic acid containing $0.03 \mathrm{~g}$ sodium acetate (anhydrous) was added $200 \mu 132 \%$ peracetic acid. The slurry was stirred vigorously for $2 \mathrm{~h}$ at room temperature. Subsequently, $10 \mathrm{ml}$ water was added to the reaction mixture, and the $\mathrm{pH}$ of the solution was adjusted to 7 with sodium hydroxide. The lactones present in the reaction mixture were a mixture of 4-isopropenyl-7-methyl-2-oxo-oxepanone (79\%) and 6-isopropenyl-3-methyl-2-oxo-oxepanone $(21 \%)$. All other chemicals were of the highest purity commercially available.

\section{RESULTS}

\section{Studies with whole cells}

R. erythropolis DCL14 is able to grow on the 2oxygenated limonene derivatives carveol, carvone, dihydrocarvone and dihydrocarveol, as sole source of carbon and energy (van der Werf et al., 1999a). Analysis of the supernatant after growth was completed showed that all stereoisomers of the terpenoid substrates were fully metabolized. Respiration experiments using suspensions of monoterpene- and succinate-grown washed cells of R. erythropolis DCL14 were performed to obtain an indication of the carveol and dihydrocarveol degradation pathways in this strain (Table 1). Oxidation of the 2-oxygenated limonene derivatives was only observed with cells grown on monoterpenes. With (4R)-limonene- and (4S)-carveol-grown cells, much lower oxidation rates with $(4 R)$-carveol and $(4 R)$ carvone were observed than with cells grown on $(4 R)$ carveol, while the oxidation rates with $(4 S)$-carveol and $(4 S)$-carvone were comparable with all terpene growth substrates. Succinate-grown cells did not significantly oxidize any of the monoterpenes tested (Table 1 ).

\section{Carveol dehydrogenase activity}

Cell extracts of monocyclic-monoterpene-grown cells of $R$. erythropolis DCL14 contained NAD ${ }_{-}^{+}, \mathrm{DCPIP}_{-}$and (very low) $\mathrm{NADP}^{+}$-dependent carveol dehydrogenase activities (Fig. 1, Table 2). While the DCPIP-dependent carveol dehydrogenase activity was mainly induced after growth on limonene, the $\mathrm{NAD}^{+}$-dependent activity was more strongly induced after growth on carveol and dihydrocarveol. Anion-exchange experiments showed that in cell extracts of limonene-grown cells, up to three different $\mathrm{NAD}^{+}$-dependent carveol dehydrogenases could be detected (van der Werf et al., 1999a). Remarkably, the $\mathrm{NAD}^{+}$-dependent $(4 R)$-carveol dehydrogenase activity was also high in succinate-grown cells.

During the $\mathrm{NAD}^{+}$-dependent conversion of a diastereomeric mixture of $(4 R)$-carveol, the $(6 S)$ stereoisomer was converted with concomitant formation of $(4 R)$-carvone, while the $(6 R)$-carveol stereoisomer was barely converted at all (Fig. 2). Similar results were obtained with a diastereomeric mixture of $(4 S)$-carveol; in this case also, only the $(6 S)$-stereoisomer was converted at a considerable rate, with quantitative formation of $(4 S)$-carvone (data not shown). Previously, we showed that when purified DCPIP-dependent carveol dehydrogenase was incubated with a diastereomeric mixture of $(4 R)$ - or $(4 S)$-carveol, it stereoselectively catalysed the conversion of the $(6 S)$-carveol stereoisomers only (van der Werf et al., 1999b). However, when DCPIP-dependent carveol dehydrogenase was incubated with the pure carveol stereoisomers, the $(6 R)$ stereoisomers of carveol were also converted, at $35 \%$ of the $(6 S)$-carveol conversion rate.

\section{Carvone reductase activity}

Cell extracts of monoterpene-grown cells of $R$. erythropolis DCL14 contained carvone reductase activity (Fig. 1, Table 2). This activity was independent of

Table 1. Oxygen uptake rates by washed-cell suspensions of $R$. erythropolis DCL14 incubated with various substrates

\begin{tabular}{|c|c|c|c|c|c|}
\hline \multirow[t]{2}{*}{ Substrate } & \multicolumn{5}{|c|}{$\begin{array}{c}\text { Oxygen uptake rate }\left[\mathrm{nmol} \mathrm{O}_{2} \min ^{-1}\left(\mathrm{mg}_{\text {protein }}\right)^{-1}\right] \\
\text { by cells grown on: }\end{array}$} \\
\hline & $\begin{array}{l}(4 R)- \\
\text { Limonene }\end{array}$ & $\begin{array}{l}(4 R)- \\
\text { Carveol }\end{array}$ & $\begin{array}{l}(4 S)- \\
\text { Carveol }\end{array}$ & $\begin{array}{l}(4 R)- \\
\text { Dihydrocarveol }\end{array}$ & Succinate \\
\hline (4R)-Limonene & 195 & 50 & 15 & 20 & $<1$ \\
\hline (4S)-Limonene & 160 & 20 & 20 & 20 & $<1$ \\
\hline$(4 R)$-Carveol & 60 & 175 & 85 & 50 & $<1$ \\
\hline$(4 S)$-Carveol & 190 & 185 & 215 & 240 & 7 \\
\hline$(4 R)$-Carvone & 50 & 145 & 90 & 50 & $<1$ \\
\hline$(4 S)$-Carvone & 180 & 190 & 210 & 150 & $<1$ \\
\hline (4R)-Dihydrocarvone & 360 & 250 & 185 & 200 & $<1$ \\
\hline (4R)-Dihydrocarveol & 95 & 300 & 60 & 165 & $<1$ \\
\hline$(4 S)$-Dihydrocarveol & 350 & 200 & 180 & 240 & $<1$ \\
\hline Succinate & $<2$ & 7 & 4 & 7 & 160 \\
\hline
\end{tabular}


Table 2. Specific activities of enzymes involved in carveol and dihydrocarveol degradation in extracts of $R$. erythropolis DCL14 cells grown on various carbon sources

\begin{tabular}{|c|c|c|c|c|c|}
\hline \multirow[t]{2}{*}{ Enzyme } & \multicolumn{5}{|c|}{ Specific activity $\left[\mathrm{nmol} \mathrm{min}^{-1}(\mathrm{mg} \text { protein })^{-1}\right]$ of cells grown on: } \\
\hline & $\begin{array}{c}(4 R)- \\
\text { Limonene }\end{array}$ & $\begin{array}{c}(4 R)- \\
\text { Carveol }\end{array}$ & $\begin{array}{c}(4 S)- \\
\text { Carveol }\end{array}$ & $\begin{array}{c}(4 R)- \\
\text { Dihydrocarveol }\end{array}$ & Succinate \\
\hline \multicolumn{6}{|c|}{$(4 R)$-Carveol dehydrogenase } \\
\hline $\mathrm{NAD}^{+}$-dependent & 17 & 45 & 45 & 36 & 19 \\
\hline $\mathrm{NADP}^{+}$-dependent & 2 & 5 & 6 & 5 & 7 \\
\hline DCPIP-dependent & 90 & 14 & 9 & 12 & $<1$ \\
\hline \multicolumn{6}{|c|}{ (4S)-Carveol dehydrogenase } \\
\hline $\mathrm{NAD}^{+}$-dependent & 9 & 21 & 15 & 17 & 4 \\
\hline $\mathrm{NADP}^{+}$-dependent & 5 & 2 & 1 & 2 & 1 \\
\hline DCPIP-dependent & 105 & 14 & 10 & 13 & $<1$ \\
\hline$(4 R)$-Carvone reductase & 9 & 14 & 23 & 12 & $<0.5$ \\
\hline$(4 S)$-Carvone reductase & 5 & 6 & 32 & 6 & $<0.5$ \\
\hline $\begin{array}{l}\text { (4R)-Dihydrocarvone } \\
\text { monooxygenase }\end{array}$ & 145 & 215 & 205 & 148 & 1 \\
\hline$\varepsilon$-Lactone hydrolase* & 9700 & 13000 & 6500 & 10000 & 30 \\
\hline \multicolumn{6}{|l|}{$\begin{array}{l}(4 R) \text {-Dihydrocarveol } \\
\text { dehydrogenase }\end{array}$} \\
\hline $\mathrm{NAD}^{+}$-dependent & 5 & 12 & 16 & 17 & 8 \\
\hline $\mathrm{NADP}^{+}$-dependent & 1 & 2 & 1 & 3 & 3 \\
\hline DCPIP-dependent & 38 & 5 & 5 & 6 & $<1$ \\
\hline \multicolumn{6}{|l|}{$\begin{array}{l}(4 S) \text {-Dihydrocarveol } \\
\text { dehydrogenase }\end{array}$} \\
\hline $\mathrm{NAD}^{+}$-dependent & 4 & 7 & 8 & 31 & 6 \\
\hline $\mathrm{NADP}^{+}$-dependent & 1 & 1 & 1 & 3 & 1 \\
\hline DCPIP-dependent & 28 & 4 & 4 & 5 & $<1$ \\
\hline Isocitrate lyase & 22 & 34 & 44 & 22 & $<1$ \\
\hline L-Malate dehydrogenase & 10 & 32 & 12 & 10 & 19 \\
\hline
\end{tabular}

*Activity with $\varepsilon$-caprolactone as the substrate.

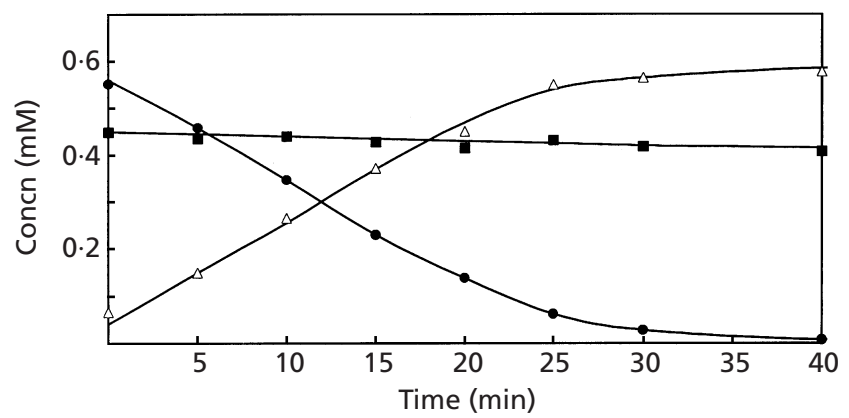

Fig. 2. $N A D^{+}$-dependent conversion of a diastereomeric mixture of $(4 R)$-carveol by extracts of $(4 R)$-carveol-grown cells of $R$. erythropolis $\mathrm{DCL} 14$. The reaction mixture $\left(30^{\circ} \mathrm{C}\right)$ contained cell extract $\left(0.94 \mathrm{mg}\right.$ protein $\left.\mathrm{ml}^{-1}\right), 50 \mathrm{mM}$ glycine/NaOH buffer $(\mathrm{pH}$ 10.5), $1.5 \mathrm{mM} \mathrm{NAD}^{+}$and $1 \mathrm{mM}(4 R)$-carveol. $\mathbf{\square},(4 R, 6 R)$-Carveol; , $(4 R, 6 S)$-carveol; $\triangle$, (4R)-carvone.

externally added cofactors such as NADH or NADPH. Carvone reductase activity was optimal at $\mathrm{pH}$ 8. Dialysis resulted in a complete loss of carvone reductase ac- tivity; this activity could not be restored by the addition of NADH or NADPH to the assay. Also a combination of either NADH or NADPH with FAD $(0 \cdot 01 \mathrm{mM})$, FMN $(0 \cdot 01 \mathrm{mM}), \mathrm{NAD}^{+}, \mathrm{NADP}^{+}, \mathrm{ZnSO}_{4}(0 \cdot 1 \mathrm{mM}), \mathrm{FeSO}_{4}$ $(0 \cdot 1 \mathrm{mM}), \mathrm{Na}_{2} \mathrm{MoO}_{4}(0 \cdot 1 \mathrm{mM}), \mathrm{CuSO}_{4}(0 \cdot 1 \mathrm{mM}), \mathrm{CoCl}_{2}$ (0.1 mM), $\mathrm{CaCl}_{2}(1 \mathrm{mM}), \mathrm{MnCl}_{2}(1 \mathrm{mM}), \mathrm{MgCl}_{2}$ (1 or 10 $\mathrm{mM}$ ) or $\mathrm{NH}_{4} \mathrm{Cl}(10$ or $50 \mathrm{mM}$ ) could not restore carvone reductase activity. However, when a cofactor fraction, prepared from cell extracts of R. erythropolis DCL14 by ultrafiltration, was added to the dialysed cell extract, the carvone reductase activity was restored. The cofactor fraction was most active when prepared from monoterpene-grown cells and maximal activity was observed when $\geqslant 400 \mu \mathrm{l}$ cofactor fraction was added to $200 \mu \mathrm{l}$ of dialysed cell extract in $1 \mathrm{ml}$ total reaction volume. The preparation of a cofactor fraction from ethanol-, isobutyrate- or succinate-grown cells resulted in lower carvone reductase activities. The cofactor fraction was stable upon heat treatment $(10 \mathrm{~min}$, $100{ }^{\circ} \mathrm{C}$ ), indicating that it is not a protein. The cofactor fraction alone did not catalyse the conversion of carvone. Storage of the cofactor fraction under aerobic conditions or in the light did not affect carvone reductase 


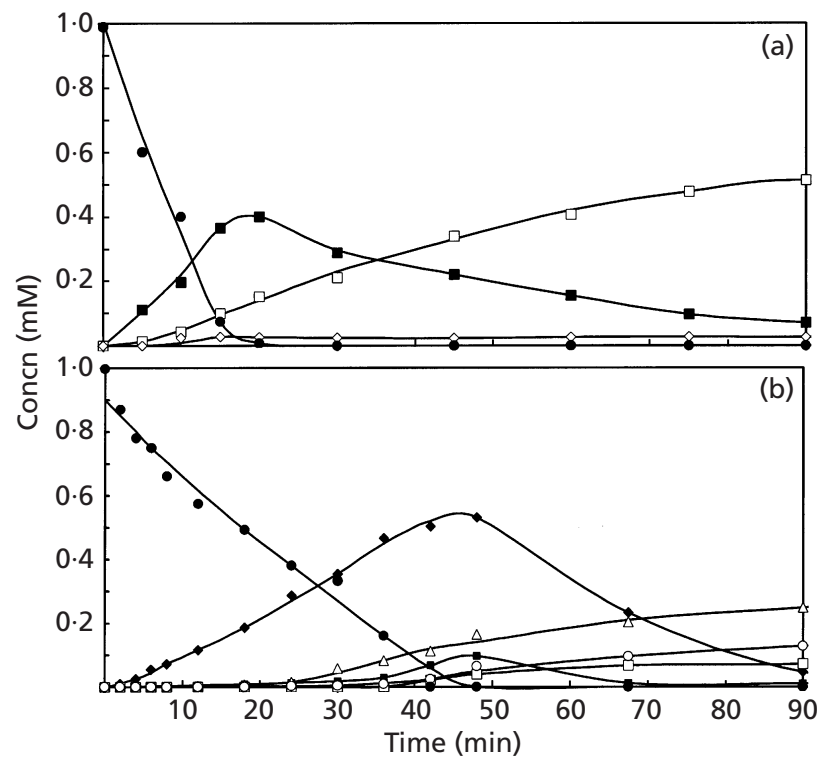

Fig. 3. Conversion of carvone under anaerobic conditions by cell extracts of (4R)-carveol-grown cells of $R$. erythropolis DCL14. (a) Conversion of (4R)-carvone. (b) Conversion of (4S)carvone. The reaction mixture $\left(30^{\circ} \mathrm{C}\right)$ contained cell extract $\left(0.94 \mathrm{mg}\right.$ protein $\left.\mathrm{ml}^{-1}\right), 50 \mathrm{mM}$ Tris/ $\mathrm{HCl}$ buffer $(\mathrm{pH} 8.0), 400 \mu \mathrm{l}$ cofactor fraction and $1 \mathrm{mM}$ carvone. 0 , Carvone; $\mathbf{\square}$ dihydrocarvone; $\diamond$, iso-dihydrocarvone; $\square$, dihydrocarveol; $\diamond$, neo-dihydrocarveol; $\triangle$, iso-dihydrocarveol; $\bigcirc$, neoiso-dihydrocarveol.

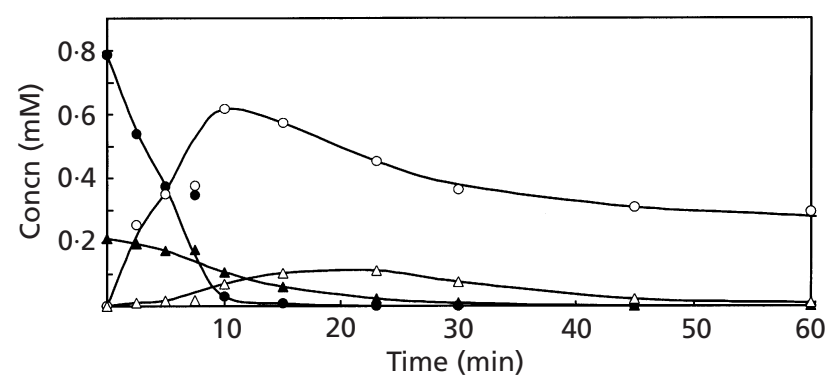

Fig. 4. Conversion of a diastereomeric mixture of (4R)dihydrocarvone by partially purified dihydrocarvone monooxygenase from (4R)-limonene-grown cells of $R$. erythropolis DCL14. The reaction mixture $\left(30^{\circ} \mathrm{C}\right)$ contained partially purified enzyme $\left(0.56 \mathrm{mg}\right.$ protein $\left.\mathrm{ml}^{-1}\right), 50 \mathrm{mM}$ Tris/HCl buffer $(\mathrm{pH} 8.0), 1.5 \mathrm{mM} \mathrm{NADPH}$ and $1 \mathrm{mM}$ (4R)-dihydrocarvone. ., $(1 R, 4 R)$-Dihydrocarvone; $\boldsymbol{\Lambda},(1 S, 4 R)$-iso-dihydrocarvone; $\bigcirc$, $(4 R, 7 R)$-4-isopropenyl-7-methyl-2-oxo-oxepanone; $\triangle$, (3S,6R)-6isopropenyl-3-methyl-2-oxo-oxepanone.

activity, indicating that the cofactor is not $\mathrm{FADH}_{2}$ or $\mathrm{FMNH}_{2}$.

During the conversion of carvone under aerobic conditions, only traces of (iso-)dihydrocarvone accumulated. However, under anaerobic conditions much larger quantities of these compounds accumulated (Fig. 3). With $(4 R)$-carvone as the substrate, the transient ac- cumulation of $(1 R, 4 R)$-dihydrocarvone was observed (Fig. 3a). Upon longer incubation, this compound was converted mainly into $(1 R, 2 R, 4 R)$-dihydrocarveol and traces of $(1 R, 2 S, 4 R)$-neo-dihydrocarveol. As no $\mathrm{NAD}(\mathrm{P}) \mathrm{H}$ was present in the reaction mixture $(<0.01$ $\mathrm{mM}$ ), this suggests that the same electron donor, or even a second unknown electron donor present in the cofactor fraction, is involved in the reduction of dihydrocarvone to dihydrocarveol. Previously, we described the purification and characterization of a DCPIP-dependent carveol dehydrogenase (van der Werf et al., 1999b), which also catalyses the oxidation of dihydrocarveol to dihydrocarvone. The physiological electron acceptor of this enzyme is unknown. Possibly, an electron donor present in the cofactor fraction acts as the cofactor for the reduction of dihydrocarvone to dihydrocarveol by DCPIP-dependent carveol dehydrogenase.

With $(4 S)$-carvone as the substrate, $(1 R, 4 S)$-isodihydrocarvone accumulated transiently (Fig. 3b). This compound was subsequently converted to $(1 R, 2 R, 4 S)$ iso-dihydrocarveol and $(1 R, 2 S, 4 S)$-neoiso-dihydrocarveol. After $30 \mathrm{~min}$, the transient accumulation of $(1 S, 4 S)$-dihydrocarvone was also observed; this compound was subsequently converted to $(1 S, 2 S, 4 S)$ dihydrocarveol and traces of $(1 S, 2 R, 4 S)$-neo-dihydrocarveol.

\section{Iso-dihydrocarvone isomerase activity}

Indications of the presence of an iso-dihydrocarvone isomerase activity in cell extracts of $R$. erythropolis DCL14, catalysing the conversion of $(1 R, 4 S)$-isodihydrocarvone to $(1 S, 4 S)$-dihydrocarvone (Fig. 1), came from the experiment shown in Fig. 3(b). Only after $30 \mathrm{~min}$ of reaction did dihydrocarvone accumulate from the iso-dihydrocarvone formed from (4S)-carvone. Unfortunately, only a diastereomeric mixture of $(4 R)$ dihydrocarvone is commercially available and the ratio of the two dihydrocarvone stereoisomers in this mixture is the same as the equilibrium for the isomerization reaction (Noma et al., 1975). Therefore, (4R)-dihydrocarvone enriched in $(1 S, 4 R)$-iso-dihydrocarvone $(80 \%)$ was prepared by preparative GC. Attempts to accumulate dihydrocarvone from iso-dihydrocarvone in incubations with cell extracts were not successful, due to the much higher (iso-)dihydrocarvone-degrading activities. With dialysed cell extracts, $(1 R, 4 R)$-dihydrocarvone was formed from $(1 S, 4 R)$-iso-dihydrocarvone (not shown), but the reaction rate $\left[0.6 \mathrm{nmol} \mathrm{m^{-1 }}(\mathrm{mg}\right.$ protein $)^{-1}$ ] was much lower than that estimated for $(1 R, 4 S)$-iso-dihydrocarvone from the data in Fig. 3(b) [6 $\mathrm{nmol} \mathrm{min}^{-1}(\mathrm{mg} \text { protein })^{-1}$.

\section{Dihydrocarvone 1,2-monooxygenase activity}

An inducible dihydrocarvone monooxygenase activity was present in R. erythropolis DCL14 (Fig. 1, Table 2). This Baeyer-Villiger type of monooxygenase was NADPH-dependent and showed optimal activity at $\mathrm{pH}$ 8. No activity was detectable when NADH was used 
Table 3. Mass spectral data of novel intermediates in the (dihydro)carveol degradation pathway of $R$. erythropolis DCL14

\begin{tabular}{|lc|}
\hline Compound & Major fragmentation peaks (with relative intensities in parentheses) \\
\hline 4-Isopropenyl-7-methyl-2-oxo-oxepanone & $\mathrm{m} / z 168\left[\mathrm{M}^{+}\right](3), 153(3), 138(16), 125(17), 110(71), 95(39), 81(27), 68$ \\
& $(100), 55(24), 41(43)$ \\
6-Isopropenyl-3-methyl-2-oxo-oxepanone & $\mathrm{m} / z 168\left[\mathrm{M}^{+}\right](7), 153(7), 139(16), 125(11), 108(80), 93(37), 81(37), 67$ \\
& $(100), 55(43), 41(55)$ \\
6-Hydroxy-3-isopropenylheptanoate & $\mathrm{m} / z 168\left[\mathrm{M}^{+}-\mathrm{H}_{2} \mathrm{O}\right](12), 153(9), 139(11), 126(49), 108(100), 93(39), 80$ \\
& $(32), 68(67), 55(27), 43(29)$ \\
6-Hydroxy-5-isopropenyl-2-methylhexanoate & $\mathrm{m} / z 168\left[\mathrm{M}^{+}-\mathrm{H}_{2} \mathrm{O}\right](11), 156(12), 138(19), 124(29), 109(50), 95(33), 82$ \\
& $(100), 68(50), 55(33), 41(27)$ \\
\hline
\end{tabular}

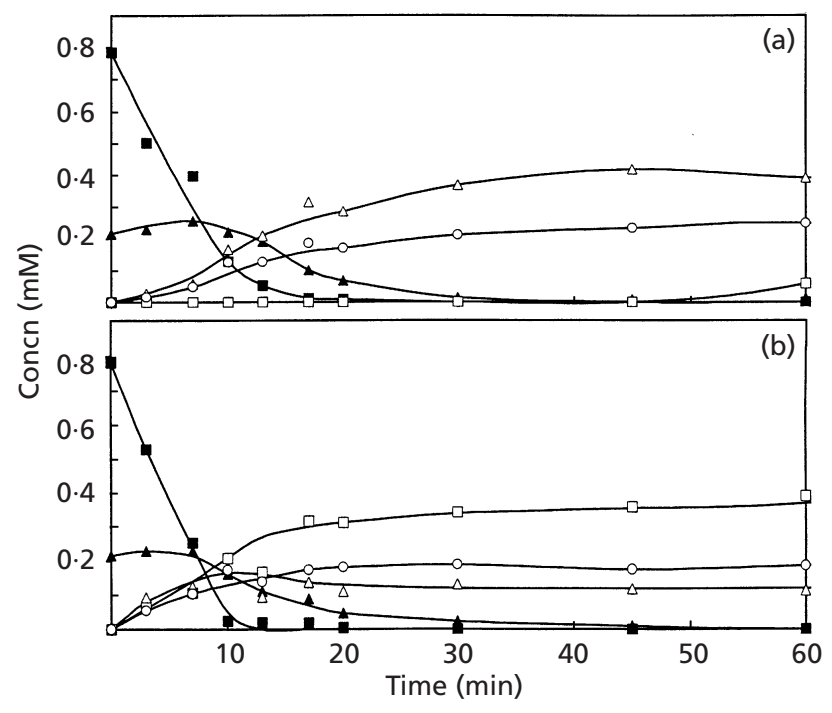

Fig. 5. Conversion of (4R)-dihydrocarvone in the absence (a) or presence (b) of $\mathrm{NAD}^{+}$by cell extracts of $(4 R)$-limonene-grown cells of $R$. erythropolis DCL14. The reaction mixture $\left(30^{\circ} \mathrm{C}\right)$ contained cell extract $\left(0.57 \mathrm{mg}\right.$ protein $\left.\mathrm{ml}^{-1}\right), 50 \mathrm{mM}$ Tris $/ \mathrm{HCl}$ buffer (pH 8.0), 1.5 mM NADPH, (1.5 mM NAD ${ }^{+}$) and $1 \mathrm{mM}(4 R)$ dihydrocarvone. $\mathbf{\square},(1 R, 4 R)$-Dihydrocarvone; $\boldsymbol{\Delta},(1 S, 4 R)$-isodihydrocarvone; $\square$, (3R)-3-isopropenyl-6-oxoheptanoate; $\triangle$, (3R)-6-hydroxy-3-isopropenylheptanoate; $\bigcirc$, (5R)-6-hydroxy-5isopropenyl-2-methylhexanoate.

as the cofactor. In the absence of oxygen, the conversion of dihydrocarvone was no longer observed.

No product accumulation was observed with either crude or dialysed cell extracts. Therefore, dihydrocarvone monooxygenase was partially purified by hydrophobic interaction chromatography, largely removing the lactone hydrolase activity. Now, the transient accumulation of two products was observed from a diastereomeric mixture of $(1 R, 4 R)$-dihydrocarvone and $(1 S, 4 R)$-iso-dihydrocarvone (Fig. 4). The products were identified by comparing the retention times after chiral and non-chiral GC, their mass spectra (Table 3) and their ${ }^{1} \mathrm{H}-\mathrm{NMR}$ and ${ }^{13} \mathrm{C}-\mathrm{NMR}$ spectra with those of standards synthesized chemically and literature data (Alphand \& Furstoss, 1992). This identified the major product as 4-isopropenyl-7-methyl-2-oxo-oxepanone and the minor product as 6-isopropenyl-3-methyl-2oxo-oxepanone. The later product is due to $(1 S, 4 R)$-isodihydrocarvone 2,3-monooxygenase activity of the same Baeyer-Villiger monooxygenase that catalyses the oxidation of $(1 R, 4 R)$-dihydrocarvone (van der Werf, 2000).

\section{Conversion of the lactones of dihydrocarvone}

When cell extracts were incubated with a diastereomeric mixture of (4R)-dihydrocarvone and NADPH, two products accumulated (Fig. 5a). Upon longer incubation, traces of 3-isopropenyl-6-oxoheptanoate, a metabolite previously identified as an intermediate in the limonene degradation pathway of this micro-organism (van der Werf et al., 1999a), also accumulated. When $\mathrm{NAD}^{+}$was also added to the reaction mixture, less of the major product in the incubation without $\mathrm{NAD}^{+}$accumulated, while 3-isopropenyl-6-oxoheptanoate was now the major product (Fig. $5 \mathrm{~b}$ ). This indicates that one of the products accumulating is 6-hydroxy-3-isopropenylheptanoate, which is converted into 3-isopropenyl-6oxoheptanoate by an $\mathrm{NAD}^{+}$-dependent hydroxy acid dehydrogenase (Fig. 1). The nature of this compound was confirmed by GC-MS analyses (Table 3). 6Hydroxy-3-isopropenylheptanoate is the result of $\varepsilon$ lactone hydrolase activity acting on 4-isopropenyl-7methyl-2-oxo-oxepanone, the major lactone formed from a diastereomeric mixture of dihydrocarvone (Figs 1 and 4). The degradation of 3-isopropenyl-6oxoheptanoate was described previously (van der Werf et al., 1999a); it is metabolized further via the $\beta$ oxidation pathway, as indicated by the elevated isocitrate lyase activities (Table 2).

The second product has the same $\mathrm{m} / \mathrm{z}$ peak of 168 $\left[\mathrm{M}^{+}-\mathrm{H}_{2} \mathrm{O}\right]$ as 6-hydroxy-3-isopropenylheptanoate and shows a similar fragmentation pattern (Table 3 ). Most likely, this product is 6-hydroxy-5-isopropenyl-2methylhexanoate, the result of the action of $\varepsilon$-lactone hydrolase on 6-isopropenyl-3-methyl-2-oxo-oxepanone, the lactone formed due to 2,3-monooxygenase activity 
Table 4. Conversion of carvone into fatty acids by cell extracts of ( $4 R$ )-carveol-grown cells of $R$. erythropolis DCL14

The reaction mixture $\left(1 \mathrm{~h}, 30^{\circ} \mathrm{C}\right)$ contained cell extract $\left(50 \%, \mathrm{v} / \mathrm{v} ; 6.0 \mathrm{mg}\right.$ protein $\left.\mathrm{ml}^{-1}\right), 50 \mathrm{mM}$ potassium phosphate buffer $(\mathrm{pH} 7 \cdot 0), 1 \cdot 5 \mathrm{mM}$ NADPH and $1 \mathrm{mM}$ carvone.

\begin{tabular}{|c|c|c|c|}
\hline \multirow[t]{2}{*}{ Substrate } & \multicolumn{3}{|c|}{ Fatty acids accumulating $(\mathrm{mM})$} \\
\hline & $\begin{array}{l}\text { 6-Hydroxy-3- } \\
\text { isopropenyl- } \\
\text { heptanoate }\end{array}$ & $\begin{array}{l}\text { 3-Isopropenyl-6- } \\
\text { oxoheptanoate }\end{array}$ & $\begin{array}{c}\text { 6-Hydroxy-5- } \\
\text { isopropenyl-2- } \\
\text { methylhexanoate }\end{array}$ \\
\hline (4R)-Carvone & trace & $0 \cdot 28$ & $0 \cdot 15$ \\
\hline (4S)-Carvone & $0 \cdot 04$ & $0 \cdot 65$ & trace \\
\hline
\end{tabular}

(Figs 1 and 4). We have been unable to demonstrate the metabolism of 6-hydroxy-5-isopropenyl-2-methylhexanoate in the presence of $\mathrm{NAD}^{+}, \mathrm{NADP}^{+}$or DCPIP, suggesting that this compound does not accumulate in vivo due to the presence of iso-dihydrocarvone isomerase activity.

Unfortunately, $(4 S)$-dihydrocarvone was not available to us. However, when cell extracts were incubated with either $(4 R)$ - or $(4 S)$-carvone, the same three hydroxy acids accumulated, as detected in incubations with $(4 R)$ dihydrocarvone (Table 4). This indicates that the $(4 S)$ (iso-)dihydrocarvone stereoisomers are degraded via a similar degradation pathway as that of (4R)-(iso-)dihydrocarvone. With both substrates, 3-isopropenyl6-oxoheptanoate was the major product. With $(4 R)$ carvone, which is directly converted to $(1 R, 4 R)$ dihydrocarvone (see Fig. 1), of the products formed, $35 \%$ is 6-hydroxy-5-isopropenyl-2-methylhexanoate, which is thought to be the dead-end product. This result again points towards the involvement of iso-dihydrocarvone isomerase activity in the (dihydro) carveol degradation pathway of R. erythropolis DCL14. With $(4 S)$ carvone, no 6-hydroxy-5-isopropenyl-2-methylhexanoate accumulated (Table 4).

\section{Dihydrocarveol dehydrogenase}

As with carveol dehydrogenase, cell extracts of $R$. erythropolis DCL14 contain $\mathrm{NAD}^{+}-, \mathrm{NADP}^{+}$- and DCPIP-dependent dehydrogenase activities (Fig. 1, Table 2). The induction patterns of carveol dehydrogenase and dihydrocarveol dehydrogenase are also similar: the $\mathrm{NAD}^{+}$-dependent dihydrocarveol dehydrogenase activity is high in carveol- and dihydrocarveolgrown cells, while the DCPIP-dependent dihydrocarveol dehydrogenase activity is high in limonene-grown cells. This suggests that, as for DCPIP-dependent carveol dehydrogenase, which was previously shown to catalyse the conversion of both carveol and dihydrocarveol (van der Werf et al., 1999b), the NAD (P) $)^{+}$-dependent carveol dehydrogenases also catalyse the conversion of both carveol and dihydrocarveol.
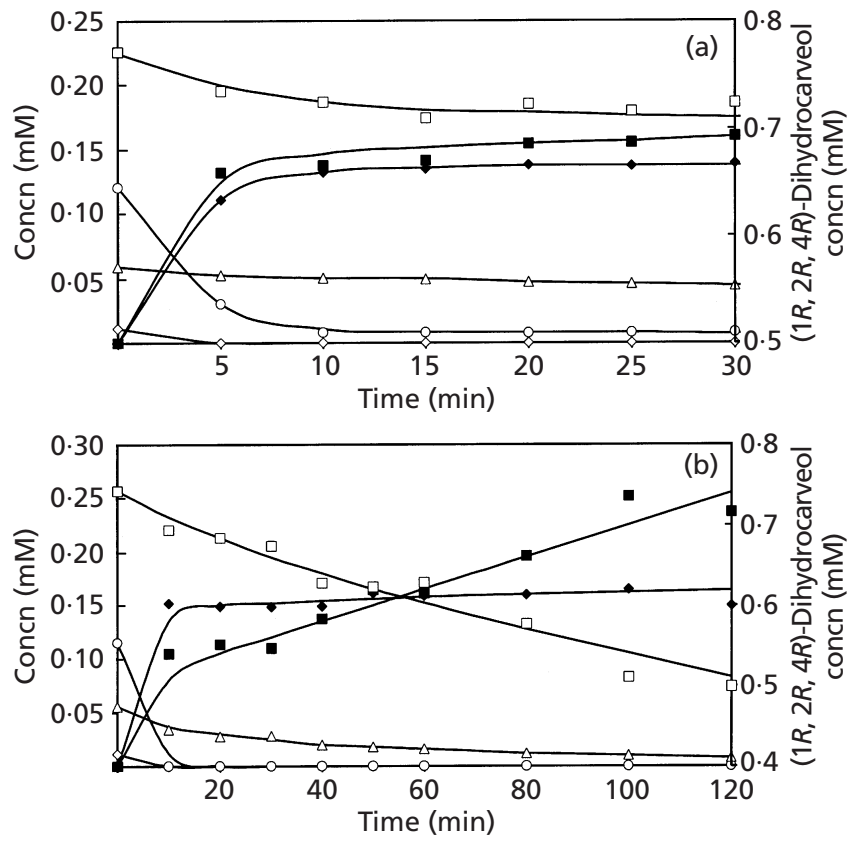

Fig. 6. Conversion of a diastereomeric mixture of (4R)dihydrocarveol by cell extracts of $R$. erythropolis DCL14. (a) Conversion in the presence of $\mathrm{NAD}^{+}$; the reaction mixture $\left(30^{\circ} \mathrm{C}\right)$ contained cell extract from $(4 R)$-dihydrocarveol-grown cells $\left(1.4 \mathrm{mg}\right.$ protein $\left.\mathrm{ml}^{-1}\right), 50 \mathrm{mM}$ glycine/NaOH buffer $(\mathrm{pH}$ 10.5), $1.5 \mathrm{mM} \mathrm{NAD}{ }^{+}$and $1 \mathrm{mM}$ (4R)-dihydrocarveol. (b) Conversion in the presence of DCPIP; the reaction mixture $\left(30^{\circ} \mathrm{C}\right)$ contained cell extract from (4R)-limonene-grown

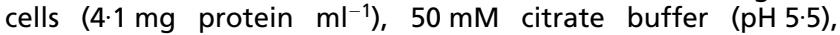
$1.5 \mathrm{mM}$ DCPIP and $1 \mathrm{mM}(4 R)$-dihydrocarveol. $\quad(1 R, 4 R)$ Dihydrocarvone; $\diamond,(1 S, 4 R)$-iso-dihydrocarvone; $\diamond,(1 R, 2 S, 4 R)$ neo-dihydrocarveol; $\square$, $(1 R, 2 R, 4 R)$-dihydrocarveol; $\triangle$, $(1 S, 2 S, 4 R)$ iso-dihydrocarveol; $O,(1 S, 2 R, 4 R)$-neoiso-dihydrocarveol.

With $(4 R)$-dihydrocarveol, the $(1 S, 2 R, 4 R)$-neoisodihydrocarveol stereoisomer, and possibly also the $(1 S, 2 S, 4 R)$-iso-dihydrocarveol stereoisomer, were converted fastest by the $\mathrm{NAD}^{+}$-dependent dihydrocarveol dehydrogenase(s) (Fig. 6a). The two other (4R)dihydrocarveol stereoisomers were also converted, al- 
beit much more slowly than $(1 S, 2 R, 4 R)$-neoisodihydrocarveol. The DCPIP-dependent dihydrocarveol dehydrogenase also catalyses the conversion of all four stereoisomers of (4R)-dihydrocarveol (Fig. 6b). Again, $(1 S, 2 R, 4 R)$-neoiso-dihydrocarveol, and possibly also $(1 S, 2 S, 4 R)$-iso-dihydrocarveol, were converted fastest. With both cofactors, $(1 R, 2 R, 4 R)$-dihydrocarveol and $(1 R, 2 S, 4 R)$-neo-dihydrocarveol were converted into $(1 R, 4 R)$-dihydrocarvone, while $(1 S, 2 R, 4 R)$-neoisodihydrocarveol and $(1 S, 2 S, 4 R)$-iso-dihydrocarveol were converted into $(1 S, 4 R)$-iso-dihydrocarvone (Figs 1 and 6).

With (4S)-dihydrocarveol also, all four stereoisomers were converted both $\mathrm{NAD}^{+}$- and DCPIP-dependently (not shown). (1S,2S,4S)-Dihydrocarveol and $(1 R, 2 R, 4 S)$-iso-dihydrocarveol were converted fastest in the presence of $\mathrm{NAD}^{+}$, and $(1 S, 2 S, 4 S)$-dihydrocarveol was converted fastest in the presence of DCPIP. With both cofactors, $(1 S, 2 S, 4 S)$-dihydrocarveol and $(1 S, 2 R, 4 S)$-neo-dihydrocarveol were converted into $(1 S, 4 S)$-dihydrocarvone, while $(1 R, 2 R, 4 S)$-iso-dihydrocarveol and $(1 R, 2 S, 4 S)$-neoiso-dihydrocarveol were converted into $(1 R, 4 S)$-iso-dihydrocarvone.

\section{DISCUSSION}

This report describes the degradation of all stereoisomers of carveol and dihydrocarveol by $R$. erythropolis DCL14, a strain which is able to grow on a large number of monocyclic monoterpenes, including limonene, carvone and menthol (van der Werf et al., 1999a). Hitherto, only biotransformation studies with 2oxygenated limonene derivatives such as carveol, dihydrocarveol, carvone and dihydrocarvone have been performed with strains unable to grow on these compounds as carbon and energy source. As far as we know, previously only one other bacterium, Corynebacterium sp. RWM1, was reported to be able to grow on 2oxygenated limonene derivatives (Williams \& Trudgill, 1994), but the metabolic pathway of these compounds in this micro-organism was not reported.

The proposed degradation pathways for the stereoisomers of carveol and dihydrocarveol in R. erythropolis DCL14 are shown in Fig. 1. These pathways are supported by (i) the substrate utilization pattern of this micro-organism (van der Werf et al., 1999a), (ii) oxygen uptake experiments by induced and non-induced cells (Table 1), (iii) the presence of the (inducible) required enzymic activities (Table 2), and (iv) the product accumulation and identification studies (Figs 2-6, Tables 3 and 4).

The degradation pathway for carveol in R. erythropolis DCL14 starts with the oxidation of the alcohol group, forming carvone. The accumulation of carvone from carveol has previously been described in several bioconversion studies (Noma, 1980; Noma \& Asakawa, 1992), but the enzymes involved were not characterized. Recently, we described the purification, biochemical characterization and gene-cloning of DCPIP-dependent carveol dehydrogenase from $R$. erythropolis DCL14 (van der Werf et al., 1999b). This enzyme is a nicotinoprotein belonging to the short-chain dehydrogenase/ reductase superfamily. Kinetic studies with the pure stereoisomers of carveol showed that all four stereoisomers of carveol were converted by DCPIP-dependent carveol dehydrogenase, but due to large differences in $V_{\max } / K_{m}$ values and a simultaneous strong product inhibition by carvone, only one of the stereoisomers was converted in a diastereomeric mixture (van der Werf et al., 1999b). A similar reasoning might explain the poor conversion of the $(6 S)$-carveol stereoisomers by $\mathrm{NAD}^{+}$dependent carveol dehydrogenase(s) (Fig. 2). The gene encoding DCPIP-dependent carveol dehydrogenase was located on an operon containing genes involved in limonene degradation (van der Werf et al., 1999b; Barbirato et al., 1998). This, together with the induction experiments described in this paper (Table 2), suggests that the main physiological role of DCPIP-dependent carveol dehydrogenase, which also catalyses the conversion of limonene-1,2-diol, is in the limonene degradation pathway, while $\mathrm{NAD}^{+}$-dependent carveol dehydrogenase(s) are dedicated to the in vivo degradation of carveol.

The carvone formed by the carveol dehydrogenases was subsequently converted to (iso-)dihydrocarvone by reduction of the $\mathrm{C}=\mathrm{C}$ double bond of the cyclohexene ring by carvone reductase (Fig. 3). This is the first time that this enzymic activity has been detected in cell extracts. As with DCPIP-dependent carveol dehydrogenase (van der Werf et al., 1999b), the physiological electron donor of carvone reductase remains to be elucidated. Possibly, DCPIP-dependent carveol dehydrogenase and carvone reductase use the same electron acceptor/donor pair. Upon reduction of the double bond of either $(4 R)$ - or $(4 S)$-carvone, the chiral C-1 carbon atom formed has the $(1 R)$-configuration, resulting in the formation of $(1 R, 4 R)$-dihydrocarvone and $(1 R, 4 S)$-iso-dihydrocarvone, respectively. The same stereospecificity in the reduction of carvone was described in previous studies with whole cells (Hirata et al., 1982; Noma \& Nonomura, 1974; Noma et al., 1974; Shimoda et al., 1998; van Dyk et al., 1998). However, examples also exist where carvone is reduced to (iso-)dihydrocarvone with a mixture of the $(1 R)$ - and $(1 S)$-configuration at the C-1 carbon atom (Noma, 1980; Noma et al., 1975), although in these instances $(1 R)$-(iso-)dihydrocarvone was (initially) the major metabolite.

At this point, the stereoisomers of dihydrocarveol also enter the pathway. Both NAD ${ }^{+}$- and DCPIP-dependent dihydrocarveol dehydrogenase activities were detected in cell extracts of $R$. erythropolis DCL14 (Table 2). Dihydrocarveol and neo-dihydrocarveol are converted into dihydrocarvone, and iso-dihydrocarveol and neoiso-dihydrocarveol into iso-dihydrocarvone (Fig. 6).

The results obtained in this study suggest that in vivo, the $(1 S)$-(iso-)dihydrocarvone formed in the degradation pathways is isomerized to $(1 R)$-(iso-)dihydrocarvone. 
This is based on (i) the accumulation of $(1 R, 4 R)$ dihydrocarvone in dialysed extracts incubated with enriched $(1 S, 4 R)$-iso-dihydrocarvone, (ii) the transient accumulation of $(1 S, 4 S)$-dihydrocarvone in the experiment described in Fig. 3(b), the initial increase in $(1 S, 4 R)$-iso-dihydrocarvone concentration in Fig. 4, and the accumulation of 6-hydroxy-5-isopropenyl-2-methylhexanoate from $(4 R)$-carvone (Table 4 ), and (iii) the fact that $(1 S, 2 S, 4 S)$-dihydrocarveol is as good a growth substrate for R. erythropolis DCL14 as is $(1 R, 2 R, 4 R)$ dihydrocarveol, and that both (1S)-dihydrocarveol and $(1 S)$-iso-dihydrocarvone are completely degraded without the accumulation of the dead-end metabolite 6-hydroxy-5-isopropenyl-2-methylhexanoate in the growth medium. Such an isomerase activity has also been detected during the bioconversion of carvone by other micro-organisms (Noma et al., 1975; VerstegenKaaksma et al., 1995). Noma et al. (1975) even partially purified an iso-dihydrocarvone isomerase preparation from Pseudomonas fragi IFO 3458, and suggested that the isomerization is achieved via keto-enol tautomerization. Remarkably, this isomerization activity was highly stable against heat; after $1 \mathrm{~h}$ at $97^{\circ} \mathrm{C}, 66 \%$ of the isomerase activity still remained, suggesting that it was not an enzymic activity. Due to the low isodihydrocarvone isomerase activity in cell extracts of $R$. erythropolis DCL14, this activity could not be characterized in more detail. Therefore, it is at present unknown if this activity is due to a dihydrocarvone isomerase, or if it is due to reverse pro-1S carvone reductase activity.

The $(1 R, 4 R)$-dihydrocarvone formed in the $(4 R)$ (dihydro)carveol degradation pathway is subsequently converted by dihydrocarvone 1,2-monooxygenase activity to $(4 R, 7 R)$-4-isopropenyl-7-methyl-2-oxo-oxepanone (Fig. 4). We recently purified and characterized this type 1 Baeyer-Villiger monooxygenase, and showed that $(1 R, 4 R)$-dihydrocarvone is exclusively converted to $(4 R, 7 R)$-4-isopropenyl-7-methyl-2-oxo-oxepanone (van der Werf, 2000). This lactone is subsequently hydrolysed by $\varepsilon$-lactone hydrolase into (3R)-6-hydroxy-3isopropenylheptanoate, which is converted $\mathrm{NAD}^{+}$dependently to (3R)-3-isopropenyl-6-oxoheptanoate. This compound has recently been shown to also be an intermediate in the limonene degradation pathway of $R$. erythropolis DCL14 (van der Werf et al., 1999a). It is converted to its CoA ester and further degraded via the $\beta$-oxidation pathway (Trudgill, 1986).

The same Baeyer-Villiger monooxygenase catalysing the oxidation of $(1 R, 4 R)$-dihydrocarvone also catalyses the oxidation of $(1 S, 4 R)$-iso-dihydrocarvone but with a different regiospecificity, resulting in the formation of (3S,6R)-6-isopropenyl-3-methyl-2-oxo-oxepanone (this paper; van der Werf, 2000). This is quite remarkable as, chemically, Baeyer-Villiger oxidation occurs mostly by insertion of the oxygen atom near a carbonyl group and the most substituted adjacent carbon atom. However, Alphand \& Furstoss (1992) reported that the regiospecificity of cyclohexanone monooxygenase from Acinetobacter calcoaceticus depended on the dihydro- carvone enantiomer used as the substrate: $(1 R, 4 R)$ dihydrocarvone was converted into 6-isopropenyl3-methyl-2-oxo-oxepanone, while $(1 S, 4 S)$-dihydrocarvone was converted to 4-isopropenyl-7-methyl-2oxo-oxepanone. Remarkably, this enzyme was unable to convert $(1 S, 4 R)$-iso-dihydrocarvone (Alphand \& Furstoss, 1992). In R. erythropolis DCL14, (3S,6R)-6isopropenyl-3-methyl-2-oxo-oxepanone is hydrolysed by the $\varepsilon$-lactone hydrolase activity to 6-hydroxy-5isopropenyl-2-methylhexanoate. We have been unable to demonstrate the metabolism of this hydroxy acid. This, together with the accumulation of mostly 3-isopropenyl-6-oxoheptanoate from either (4R)- or $(4 S)$-carvone (Table 4$)$, suggests that the pathway via 6-hydroxy-5-isopropenyl-2-methylhexanoate is a deadend pathway (Fig. 1). In vivo, any (1S,4R)-iso-dihydrocarvone formed is directly isomerized to $(1 R, 4 R)$ dihydrocarvone.

Unfortunately, $(4 S)$-dihydrocarvone was not available to us, and therefore the last part of the $(4 S)$ (dihydro)carveol degradation pathway remains ambiguous (Fig. 1). Given the proximity of the 1-methyl group to the site of oxygen insertion in the correct oxidation pathway, it seems most likely that the $(1 R)$-configuration of (iso-)dihydrocarvone determines the regiospecificity of the Baeyer-Villiger monooxygenase. This hypothesis is supported by the fact that none of the dead-end product accumulated from (4S)-carvone (Table 4). Given the pro-1R specificity of carvone reductase, the product of $(4 S)$-carvone would be $(1 R, 4 S)$ iso-dihydrocarvone, which would be the main substrate for the correct oxidation pathway (Fig. 1). Alternatively, only the dihydrocarvone enantiomers are substrates for the Baeyer-Villiger monooxygenase, and the $(1 R, 4 S)$ iso-dihydrocarvone formed from $(4 S)$-carvone is, in vivo, first isomerized to $(1 S, 4 S)$-dihydrocarvone before the ring-opening reactions take place.

In conclusion, R. erythropolis DCL14 degrades the (4R)and $(4 S)$-stereoisomers of carveol via a highly homologous pathway (Fig. 1). A major difference between the $(4 R)$ - and $(4 S)$-stereoisomers is determined by the pro-1R specificity of carvone reductase, and the influence of the (iso-)dihydrocarvone stereochemistry on the regiospecificity of the Baeyer-Villiger monooxygenase. Therefore, different diastereomers of dihydrocarvone and 4-isopropenyl-7-methyl-2-oxooxepanone are intermediates in the $(4 R)$ - and $(4 S)$ (dihydro)carveol degradation pathways (Fig. 1). Moreover, iso-dihydrocarvone isomerase activity is essential in the degradation pathways of the $(1 S)$-dihydrocarveol and $(1 S)$-dihydrocarvone stereoisomers.

\section{ACKNOWLEDGEMENTS}

This work was supported by a grant form the European Community (BIO4-CT95-0049). We thank Martin de Wit for technical assistance, Willem J. B. van Berkel (Laboratory of Biochemistry, Wageningen University) and Jan A. M. de Bont (Division of Industrial Microbiology, Wageningen University) for fruitful discussions, Harm Niederlaender (Laboratory of 
Organic Chemistry, Wageningen University) for his help with preparative GC, A. van Veldhuizen (Laboratory of Organic Chemistry, Wageningen University) for recording and interpreting the NMR-data, and Henk Swarts (Laboratory of Organic Chemistry, Wageningen University) for giving us reference samples of the optically pure dihydrocarveol and dihydrocarvone stereoisomers and for the synthesis of $(4 S)$ carveol.

\section{REFERENCES}

Alphand, V. \& Furstoss, R. (1992). Microbiological transformations. 23. A surprising regioselectivity of microbiological Baeyer-Villiger oxidations of menthone and dihydrocarvone. Tetrahedron: Asymmetry 3, 379-382.

Banthorpe, D. V. (1994). Terpenoids. In Natural Products: Their Chemistry and Biological Significance, pp. 289-359. Edited by J. Mann, R. S. Davidson, J. B. Hobbs, D. V. Banthorpe \& J. B. Harborne. Harlow, UK: Longman.

Barbirato, F., Verdoes, J. C., de Bont, J. A. M. \& van der Werf, M. J. (1998). The Rhodococcus erythropolis DCL14 limonene1,2-epoxide hydrolase gene encodes an enzyme belonging to a novel class of epoxide hydrolases. FEBS Lett 438, 293-296.

Bradford, M. M. (1976). A rapid and sensitive method for the quantitation of microgram quantities of protein utilizing the principle of protein-dye binding. Anal Biochem 72, 248-254.

Buckingham, J. (1998). In Dictionary of Natural Products on CDROM, Version 6.1. London: Chapman \& Hall.

Burdock, G. A. (1995). Fenaroli's Handbook of Flavor Ingredients, 3rd edn. Boca Raton, FL: CRC Press.

van Dyk, M. S., van Rensburg, E., Rensburg, I. P. B. \& Moleleki, N. (1998). Biotransformation of monoterpenoid ketones by yeasts and yeast-like fungi. J Mol Catal B (Enzymatic) 5, 149-154.

Guenther, A., Hewitt, C. N., Erickson, D. \& 13 other authors (1995). A global model of natural volatile organic compound emissions. J Geophys Res 100, 8873-8892.

Harborne, J. B. (1991). Recent advances in the ecological chemistry of plant terpenoids. In Ecological Chemistry and Biochemistry of Plant Terpenoids, pp. 399-426. Edited by J. B. Harborne \& F. A. Tomas-Barberan. Oxford: Clarendon Press.

Hartmans, S., Smits, J. P., van der Werf, M. J., Volkering, F. \& de Bont, J. A. M. (1989). Metabolism of styrene oxide and 2phenylethanol in the styrene-degrading Xanthobacter strain 124X. Appl Environ Microbiol 55, 2850-2855.

Hirata, T., Hamada, H., Aoki, T. \& Suga, T. (1982). Stereoselectivity of the reduction of carvone and dihydrocarvone by suspensions of cells of Nicotiana tabacum. Phytochemistry 21, 2209-2212.

McCaskill, D. \& Croteau, R. (1997). Prospects for the bioengineering of isoprenoid biosynthesis. Adv Biochem Eng Biotechnol 55, 107-146.

Mironowicz, A. \& Siewiński, A. (1986). Biotransformations. XIX. Reduction of some terpenic ketones by means of immobilized cells of Rhodotorula mucilaginosa. Acta Biotechnol 6, 141-146.

Mironowicz, A., Raczkowska, J., Siewiński, A., Szykuła, J. \& Zabża, A. (1982). Microbiological transformations. Part XIV. Microbiological reduction of $(+)$-carvone and eucarvone by Rhodotorula mucilaginosa. Pol J Chem 56, 735-739.

Nishimura, H., Hiramoto, S., Mizutani, J., Noma, Y., Furusaki, A. \& Matsumoto, T. (1983). Structure and biological activity of bottrospicatol, a novel monoterpene produced by microbial transformation of (-)-cis-carveol. Agric Biol Chem 47, 2697-2699.
Noma, Y. (1980). Conversion of $(-)$-carvone by strains of Streptomyces, A-5-1, and Nocardia, 1-3-11. Agric Biol Chem 44, 807-812.

Noma, Y. \& Asakawa, Y. (1992). Enantio- and diastereoselectivity in the biotransformation of carveols by Euglena gracilis $\mathrm{Z}$. Phytochemistry 31, 2009-2011.

Noma, Y. \& Nishimura, H. (1987). Bottrospicatols, novel monoterpenes produced on conversion of $(-)$ - and $(+)$-cis-carveol by Streptomyces. Agric Biol Chem 51, 1845-1849.

Noma, Y. \& Nonomura, S. (1974). Conversion of (-)-carvone and $(+)$-carvone by a strain of Aspergillus niger. Agric Biol Chem 38, $741-744$.

Noma, Y., Nonomura, S., Ueda, H. \& Tatsumi, C. (1974). Conversion of $(+)$-carvone by Pseudomonas ovalis, strain 6-1. Agric Biol Chem 38, 735-740.

Noma, Y., Nonomura, S. \& Sakai, H. (1975). Epimerization of ( - )isodihydrocarvone to (-)-dihydrocarvone by Pseudomonas fragi IFO 3458. Agric Biol Chem 39, 437-441.

Noma, Y., Nishimura, H., Hiramoto, S., Iwami, M. \& Tatsumi, C. (1982). A new compound, $(4 R, 6 R)-(+)-6,8$-oxidomenth-1-en-9ol produced by microbial conversion of $(-)$-cis-carveol. Agric Biol Chem 46, 2871-2872.

Ravid, U., Putievsky, E., Katzir, I., Weinstein, V. \& Ikan, R. (1992). Chiral GC analysis of $(S)(+)$ - and $(R)(-)$-carvone with high enantiomeric purity in caraway, dill and spearmint oils. Flavour Fragrance J 7, 289-292.

Sauers, R. R. \& Ahearn, G. P. (1961). The importance of steric effects in the Baeyer-Villiger oxidation. J Am Chem Soc 83, 2759-2762.

Shimoda, K., Hirata, T. \& Noma, Y. (1998). Stereochemistry in the reduction of enones by the reductase from Euglena gracilis Z. Phytochemistry 49, 49-53.

Trudgill, P. W. (1986). Terpenoid metabolism by Pseudomonas. In The Bacteria. A Treatise on Structure and Function, vol. X, The Biology of Pseudomonas, pp. 483-525. Edited by J. R. Sokatch. Orlando, FL: Academic Press.

Trudgill, P. W. (1990). Microbial metabolism of monoterpenes recent developments. Biodegradation 1, 93-105.

Trudgill, P. W. (1994). Microbial metabolism and transformation of selected monoterpenes. In Biochemistry of Microbial Degradation, pp. 33-61. Edited by C. Ratledge. Dordrecht: Kluwer.

Varie, D. L., Brennan, J., Briggs, B., Cronin, J. S., Hay, D. A., Rieck, J. A. \& Zmijewski, M. J. (1998). Bioreduction of $(R)$-carvone and regioselective Baeyer-Villiger oxidations: application to the asymmetric synthesis of cryptophycin fragment A. Tetrahedron Lett 39, 8405-8408.

Verstegen-Kaaksma, A. A., Swarts, H. J., Jansen, B. J. M., de Groot, A., Bottema-MacGillavry, N. \& Witholt, B. (1995). Application of $S-(+)$-carvone in the synthesis of biologically active natural products using chemical transformations and bioconversions. Ind Crops Prod 4, 15-21.

Welsh, F. W., Murray, W. D. \& Williams, R. E. (1989). Microbiological and enzymatic production of flavor and fragrance chemicals. Crit Rev Biotechnol 9, 105-169.

van der Werf, M. J. (2000). Purification and characterization of a Baeyer-Villiger monooxygenase from Rhodococcus erythropolis DCL14 involved in three different monocyclic monoterpene degradation pathways. Biochem J (in press).

van der Werf, M. J., Guettler, M. V., Jain, M. K. \& Zeikus, J. G. (1997). Environmental and physiological factors affecting the succinate product ratio during carbohydrate fermentation by Actinobacillus sp. 130Z. Arch Microbiol 167, 332-342. 
van der Werf, M. J., Overkamp, K. M. \& de Bont, J. A. M. (1998). Limonene-1,2-epoxide hydrolase from Rhodococcus erythropolis DCL14 belongs to a novel class of epoxide hydrolases. J Bacteriol 180, 5052-5057.

van der Werf, M. J., Swarts, H. J. \& de Bont, J. A. M. (1999a). Rhodococcus erythropolis DCL14 contains a novel degradation pathway for limonene. Appl Environ Microbiol 65, 2092-2102.

van der Werf, M. J., van der Ven, C., Barbirato, F., Eppink, M. H. M., de Bont, J. A. M. \& van Berkel, W. J. (1999b). Stereoselective carveol dehydrogenase from Rhodococcus erythropolis
DCL14. A novel nicotinoprotein belonging to the short-chain dehydrogenase/reductase superfamily. J Biol Chem 274, 26296-26304.

Williams, D. R. \& Trudgill, P. W. (1994). Ring cleavage reactions in the metabolism of $(-)$-menthol and $(-)$-menthone by a Corynebacterium sp. Microbiology 140, 611-616.

Received 12 November 1999; revised 3 February 2000; accepted 7 February 2000. 